\title{
ノズルレスインクジエッ印刷による材料の ナノ・マイクロ構造制御に関する研究
}

\section{Study of nano and micron structure control of the materials by novel-free ink-jet printing}

\section{9}

$\begin{array}{llllllll}\text { 研究代表者 } & \text { 岐阜県セラミックス研究所 } & \text { 研究開発部長 } & \text { 横 } & \text { 山 } & \text { 久 } & \text { 範 } & \text { Hisanori Yokoyama } \\ \text { 共同研究者 } & \text { 大阪大学接合科学研究所 } & \text { 教授 } & \text { 内 } & \text { 藤 } & \text { 牧 } & \text { 男 } & \text { Makio Naito }\end{array}$

\begin{abstract}
Optimization of slurry for nozzle-free ink-jet forming was investigated. 10mass\% aqueous slurry of colloidal silica was prepared, and the effect of the slurry characters on the droplet formation process and the printed characters was examined. Surface tension and apparent viscosity of the slurries had the influence on the droplet formation and the printed dot diameter, and the dot diameter decreased as the viscosity increases. Using the slurry with the phosphor powder (mean particle size: $1.8 \mu \mathrm{m}$ ), the clear pattern was obtained by nozzle-free ink-jet forming.
\end{abstract}

\section{研究目的}

インクジェット印刷は, 装置がシンプルで多色化が 容易なため, 低価格のプリンターとしてパーソナル分 野に普及してきた。特に, プリンターの高精細化・高 速化とデジタルカメラやインターネットなどデジタル メディアの普及により, カラー写真や年賀状などのプ リンターとして広く利用されるに至っている。インク ジェット印刷の特徵は, コンピュータ制御による迅速 な印刷が可能, 必要な部分のみを印刷し無駄がない, 大面積化が可能, 非接触印刷などであり, 大型看板, オンデマンド捺染, 段ボールや缶などへのマーキング などの産業分野での応用も進んでいる。近年ではマス キングや真空蒸着などの複雑な工程を必要としないた め, 半導体やディスプレイ分野への展開も進んでいる。 これらの印刷の吐出方法としては, 主にピエゾ方式 とサーマル方式が使用されている ${ }^{1)}$ 。ピエゾ方式はノ ズル中のピエゾ素子の圧電変化を利用した 吐出方法
であり，サーマル方式は気泡（バブル）による体積変 化を利用した吐出方法である。これらの吐出方法によ り, 無機粉体スラリーを直接印刷し, 様々な機能材の パターン・薄膜形成などが報告されている。しかし， これらの方法は10〜50 $\mu \mathrm{m}$ のノズル径から低粘性のス ラリーを吐出させる方法であるため, 顔料などの粉体 を含むスラリーの場合, ノズル部やインク経路での粉 体沈積によりノズル詰まりが発生することから，使用 する粉体の粒子径は100nm以下に限定される ${ }^{2)} 。$ 特に, 比重の大きな無機粉体によるスラリーを用いた場合, 沈降や凝集によりノズル詰まりが発生する可能性が高 くなり，安定した吐出が課題となっている。

一方，ノズルを有しないインクジェット方法として

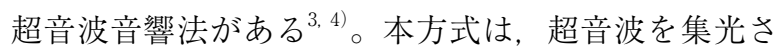
せ集光部からスラリーを吐出させる方式でノズルフリ 一なインクジェット方式であるため, 微小ノズルによ る課題を克服できる技術として期待される。しかし， 本方式による吐出試験は極めて少なく, 最適なスラリ 
一特性等が不明である。そこで，スラリー特性が吐出 特性や描画特性に及ぼす影響について基礎的な検討を 行った。さらに，ミクロンサイズの蛍光体粉体を利用 し，ノズルフリーインクジェットによりパターン印刷 を試みた。

\section{研究成果の概要}

\section{1. 実験方法}

スラリーにはコロイダルシリカスラリーZL（日産 化学製：固形分20mass\%）をイオン交換水で10mass\% に希釈したスラリーを用いた。スラリーの粘度調整は, $2 \mathrm{mass} \% \mathrm{CMC}$ 水溶液を加えることにより調製し，スラ リーの表面張力低減は湿潤剤SNウェット363（サン） プコ製）を添加した。Table.1に各スラリーの調製条
件を示す。スラリー特性として見掛け粘度を回転粘度 計（Mars II：HAKKE製）によりC60/1コーンプレー

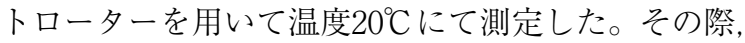
ずり速度を $10 \mathrm{~s}^{-1}$ から $1000 \mathrm{~s}^{-1}$ の範囲で 7 点を選択し， 各ずり速度での 1 分経過後の見掛け粘度を值として用 いた。また，表面表力を表面張力計（ESB-V：協和 科学製) にてウェルヘルミー法により測定した。

インクジェット装置には超音波音響法によるノズル フリーインクジェット装置ナノパレード（ホソカワミ クロン製）により吐出試験を行った。Fig.1に装置及 び吐出部の写真を，Fig.2に吐出の概念図を示す。本 吐出方法は，音響波レンズ付きの集光式超音波発振子 により超音波を集束させ，集束中心部から液滴を発生 させ, 基板上にインクジェット成形を行う方法である。 当初, Fig.2(A)に示すように集束中の容器全体にスラ リーを取り吐出試験を行った結果，スラリー濃度が高

Table.1 Slurry condition and slurry characteristics.

\begin{tabular}{|c|c|c|c|c|c|}
\hline No. & $\begin{array}{c}\text { Slurry } \\
\text { concent. } \\
/ \mathrm{mass} \%\end{array}$ & $\begin{array}{c}\text { Amount of } \\
2 \% \mathrm{CMC} \\
/ \mathrm{mass} \%\end{array}$ & $\begin{array}{c}\text { Amount of } \\
\text { agent } \\
/ \mathrm{mass} \%\end{array}$ & $\begin{array}{c}\text { Apparent } \\
\text { viscosity } \\
/ \mathrm{mPa} \cdot \mathrm{s} \\
\left(\text { shear rate: } 100^{-\mathrm{s}}\right)\end{array}$ & $\begin{array}{c}\text { Surface } \\
\text { tension } \\
/ \mathrm{mN} / \mathrm{m}\end{array}$ \\
\hline $10 \mathrm{~A}$ & 10 & 0.0 & 0.05 & 1.4 & 59.9 \\
\hline $10 \mathrm{~B}$ & 10 & 0.0 & 0.1 & 1.4 & 36.9 \\
\hline $10 \mathrm{C}$ & 10 & 0.0 & 0.15 & 6.3 & 32.7 \\
\hline $10 \mathrm{D}$ & 10 & 5.0 & 0.15 & 9.5 & 32.4 \\
\hline $10 \mathrm{E}$ & 10 & 6.0 & 0.15 & 21.7 & 33.5 \\
\hline $10 \mathrm{~F}$ & 10 & 10.0 & 0.15 & & 3.6 \\
\hline
\end{tabular}

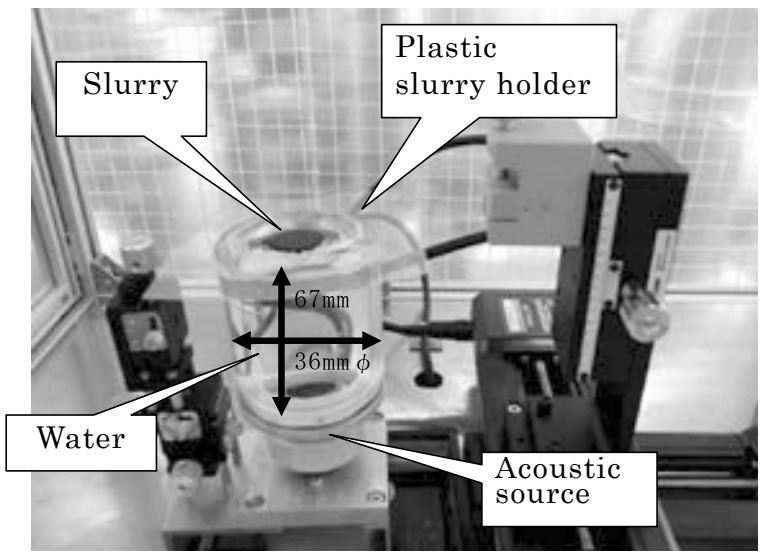

Fig.1 Photograph of delivery part of nozzle-free ink-jet forming system.

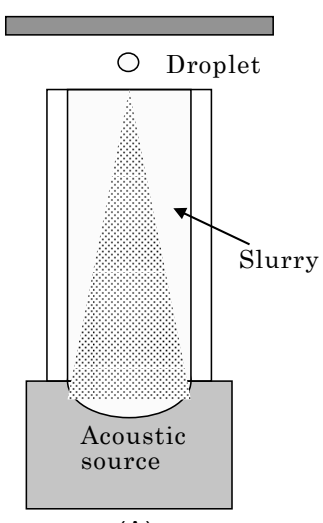

(A)

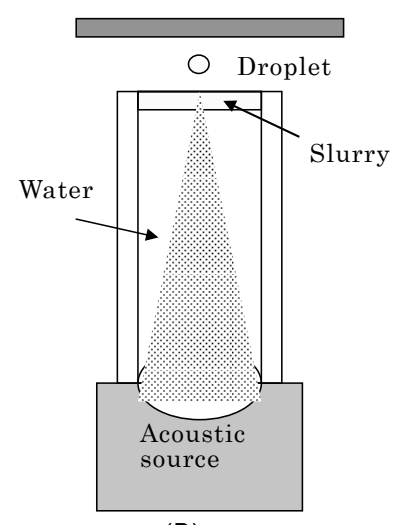

(B)
Fig.2 Schematic diagram of nozzle-free ink-jet forming system. 
くなると超音波がスラリー中に拡散して吐出すること ができなかった。そのため，Fig.2(B)に示すように集 束する部分は超音波吸収の少ない水とし, 液滴が吐出 する集束中心部のみにスラリーを分取する方式とし た。吐出状態を観察するため，八イスピードカメラ (EX-F1:カシオ計算機製）により1/300秒間隔でビデ オ撮影を行った。吐出はスラリー面から $30 \mathrm{~mm}$ 離した インクジェット印刷用OHPフィルム及びガラス基板 上にドットパターンを描画した。その際，同じ条件で 場所を変えて 5 回吐出させ，描画されたドットの直径 の平均値を求める方法により，吐出状態や描画パ夕ー ンを評価した。超音波発信子には $10.449 \mathrm{MHz}$ 素子を用 い，照射時間150～200msに変えて吐出試験を実施し た。吐出したドットの直径はマイクロスコープ(VCRFRM50LZ：オムロン製）により計測した。

ノズルフリーインクジェットの最大の特徵は, 小さ な径のノズルによるノズル詰まりの発生がないことで ある。そのため，本方式を用いることで，ノズルを有 するインクジェットでは吐出不可能な大きな粒子径の 粉体スラリーの吐出の可能性がある。そこで，蛍光粉 体によりスラリー調製を行い，ノズルフリーインクジ エット法によってパターニングを試みた。用いた蛍光 粉体は残光性のある蛍光粉体Green：NP-2830-01（日 亜化学製）であり，溶媒にブタノールを使用し，スラ リー濃度 $45 \mathrm{mass} \%$ ，直径 $2 \mathrm{~mm}$ のジルコニア製玉石を 用いて 3 日間ボールミル混合・粉砕を行った。粉砕後 の蛍光粉体の平均粒子径は約 $1.8 \mu \mathrm{m}$ であり，一部 5 $\mu \mathrm{m}$ 以上の粒子の存在が確認された。本スラリーを $7.5 \mathrm{mass} \%$ に希勫し吐出試験に用いたここで，ブタノ 一ルを溶媒として使用した理由は，蛍光粉体は耐水性 が低く，ボールミル混合・粉砕により粘性変化や溶解 が予想されるためである。

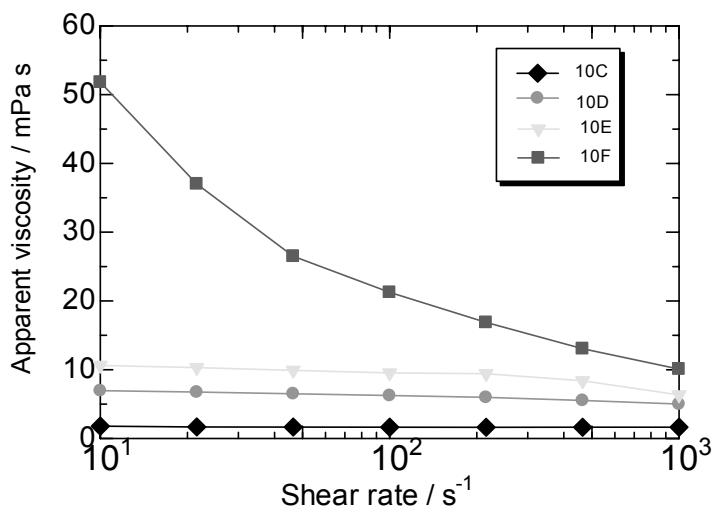

Fig.3 Shear stress and shear rate for colloidal silica slurries.

\section{2. 実験結果及び考察}

Table.1に使用したスラリーのスラリー特性を示す。 また，Fig.3にシリカスラリーのずり速度と見掛け粘 度の関係を示す。スラリー10A，10B，10Cを比較す ると, 湿潤剤添加量の増加により表面張力が低下した。 一般に使用されているインクジェット用インクの表面 張力は $20 \sim 60 \mathrm{mN} / \mathrm{m}$ であり ${ }^{1)}$ ，いずれのスラリーもそ の範囲内であった。特に，湿潤剂を $0.1 \mathrm{mass} \%$ 以上添 加することで，表面張力は $40 \mathrm{mN} / \mathrm{m}$ 以下とさくなっ た。一方， $\mathrm{CMC}$ 水溶液の添加によりスラリー粘度は 増加した。Fig.3のずり速度と粘度の関係からCMC水 溶液添加量が 6 mass\%以下のスラリーはほぼニュー トン流動を示したが，CMC水溶液を10mass\%添加し たスラリー10Fは擬塑性流動を示し, 粘度も高い值と なった。一般的なインクジェット用インクの粘度は数 $\mathrm{mPa} \cdot \mathrm{s} \sim 10 \mathrm{mPa} \cdot \mathrm{s}$ 前後の非常に低粘度スラリーが使用 され，これらのスラリーはニュートン流動を示す場合 が多い2.5)。本実験に使用したスラリーもスラリー10F 以外は全て $10 \mathrm{mPa} \cdot \mathrm{s}$ 以下でニュートン流動であり，イ ンクジェット用スラリーに適合したスラリーと考え る。

Table.2に表面張力の異なる 2 種類のスラリーを用 いて超音波照射時間200msでOHPフィルム上に描画し たドット直径について，サンプル点数は 5 点であるが 平均值及び標準偏差を示す。表面張力の小さなスラリ ー10Cはスラリー10Aに比べ，大きなドット直径とな った。鈴木らはサーマル方式インクジェットノズルを 用いて表面張力 $50 \sim 78 \mathrm{mN} / \mathrm{m}$ の液体の吐出試験を評価 し，表面張力が大きく低粘度なインクほど吐出速度が 増加するとともに，吐出速度が速いほどドット直径が 大きくなると報告している5)。この結果ではインクの 表面張力だけでなく粘度の影響もあるため, Table.2 に示す結果とは逆な傾向であった。一方，表面張力が 極めて低い液体では主液滴が吐出した後に形成される 2 次的な微小液滴（サテライト）の発生する割合が高 くなることが指摘されている5)。そこで八イスピード カメラを用いて吐出状態を観察した。その結果, 表面 張力が低く照射出力が大きな場合, サテライトの発生

Table.2 Printed dot diameter of slurry 10A and 10C.

\begin{tabular}{|c|c|c|}
\hline Slurry No. & Dot diameter/ $\mathrm{mm}$ & Standard deviation \\
\hline $10 \mathrm{~A}$ & 2.30 & 0.17 \\
\hline $10 \mathrm{C}$ & 2.55 & 0.14 \\
\hline
\end{tabular}


が認められた。また，低表面張力のスラリー10Cでは， 液面からの液滴の切れが良く, 液滴が垂直に高くまで 吐出ている様子が観察されたことから, 表面張力が小 さなスラリーの方が液面からの液滴の切れが良好であ り，その結果Table.2に示したようにドット直径が大 きくなったものと考えられる。また，スラリー10Cの 方が形成された液滴がより高くまで吐出できることも わかった。Fig.4にスラリー10Cの吐出状態の1/300s毎 の連続写真を示す。液面が下部より山状に盛り上がっ た後、液滴が形成されることが確認できる。

Fig.5にスラリーの見掛け粘度（ずり速度 $100 \mathrm{~s}^{-1}$ ) と 超音波照射時間 $180 \mathrm{~ms}$ でOHPフィルム上に描画したド ットパターンの直径の関係を示す。ドット直径はスラ リー粘度が高くなるほど小さくなった。サーマル方式 のインクジェットに拈いて，インク粘度が高くなるほ ど吐出速度及び吐出体積が減少する1,5)。また，イン ク粘度や吐出速度等より求めたレイノルズ数と紙に印 刷したドット径の関係では, レイノルズ数が高くなる ほどドット径が大きくなると報告されている5゙。レイ ノルズ数は吐出速度に比例しインク粘度に反比例する ことから，低粘度インクほどドット直径が大きくなる

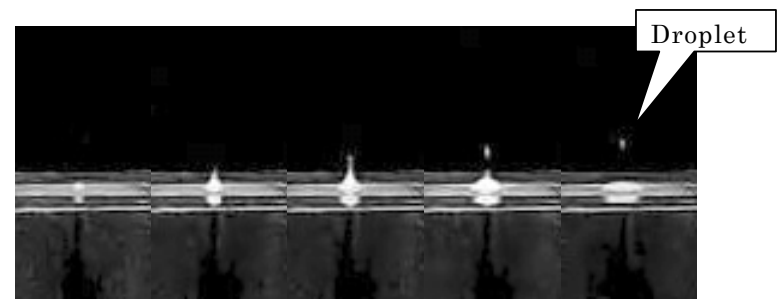

Fig.4 Photographs of droplet formation process by nozzle-free ink jet forming (slurry 10C).

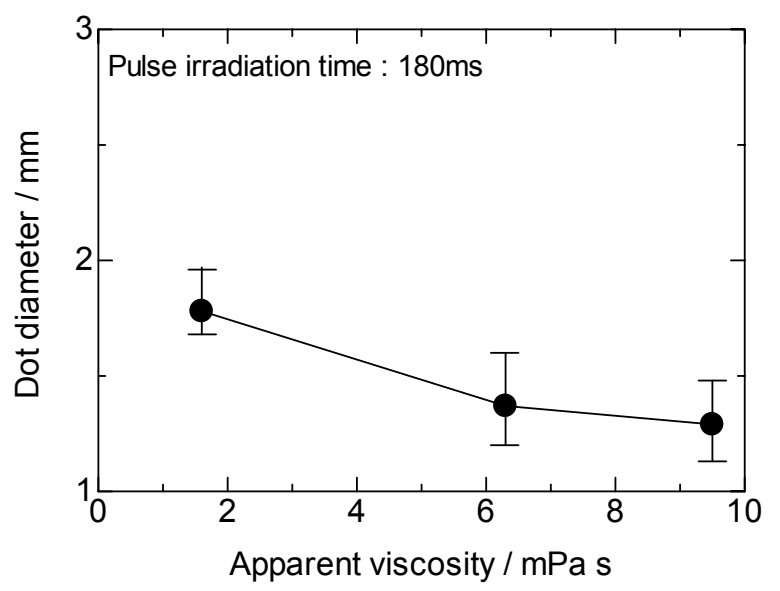

Fig.5 Relationship of apparent viscosity (shear rate: $100^{-s}$ ) of slurry and printed dot diameter.
と考えられる。ノズルフリーインクジェットにおいて も，低粘度スラリーほどドット直径が大きくなってお り, 従来の吐出方法と同様に粘度が増加するほど, 吐 出体積が減少してドット直径が小さくなったと考え る。一方，スラリー粘度が最も高くなったスラリー 10Fは，スラリー表面が上部に盛り上がるものの，液 滴を形成するに至らなかった。ノズルフリーインクジ エットでは, $50 \mathrm{mPa} \cdot$ s以下の液体の吐出が確認されて いる ${ }^{17)}$ 。しかし，スラリー10FはFig.1に示すように擬 塑性流動であり，ずり速度 $10 \mathrm{~s}^{-1}$ では粘度 $50 \mathrm{mPa} \cdot \mathrm{s}$ 以 上の粘度を有している。擬塑性流動の場合, 短時間の パルス照射では急な液滴の形成が困難であると考えら れる。このことから，ノズルフリーインクジェットに おいてもニュートン流動のスラリーを使用することが 望ましいと思われる。

通常のノズルを有するインクジェットではノズル詰 まりが発生するため, 粒子径の大きな粉体スラリーを 使用することが困難である。一方，ノズルレスインク ジェットはノズル詰まりの課題がないため,こうした スラリーの利用技術として期待される。そこで, 平均 粒子径 $1.8 \mu \mathrm{m}$ の蛍光粉体をスラリーとしてノズルレ スインクジェットのパターン印刷を試みた。調製した 蛍光粉体スラリーの表面張力は $28.1 \mathrm{mN} / \mathrm{m}$ であり, 溶 媒にブタノールを使用したためコロイダルシリカスラ リーに比べ表面張力が低くなった。一方, ずり速度 $100 \mathrm{~s}^{-1}$ における見掛け粘度は $13.7 \mathrm{mPa} \cdot \mathrm{s}$ であり，レオ ロジー的にはほぼニュートン流動を示した。

蛍光粉体スラリーを用いてノズルフリーインクジェ ットによりアルミナ基板上にドットパターンを描画し た。この時, より微細なパターンを描くため, アルミ ナ基板に撥水処理を施した。一定間隔に描画したドッ トパターンのブラックライト投光時の写真をFig.6に

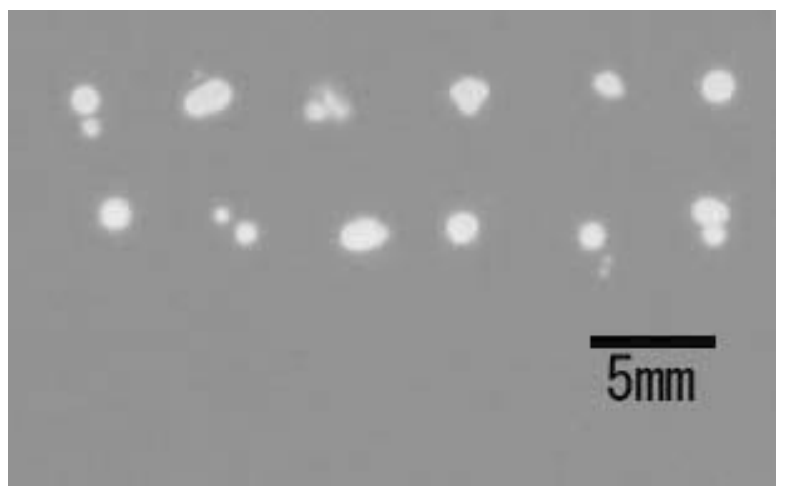

Fig.6 Photograph of printed pattern of phosphor slurry by nozzle-free ink-jet forming. 
示す。液面と基板との距離が30mmと長いことや，液 滴を下から上に吐出させるため重力の影響を受けるこ とにより，一定間隔に描画したドットのパターンの安 定性には問題があった。また，一部のパターンでは大 きな液滴と小さな液滴による 2 ドットのパターンが確 認される。小さな液滴はサテライトによるドットと考 えられ，吐出時のサテライトの存在が確認された。こ こで興味深いことは，平均粒子径 $1.8 \mu \mathrm{m}$ の蛍光粉体 スラリーによる吐出が可能であったことである。この ようなスラリーは, 従来のインクジェットではスラリ 一粘度が低く沈降が速いため，ノズル詰まりを発生さ せる恐れがある。特に, 無機粉体は比重が大きいため, その傾向が顕著である。今回，ノズルフリーのインク ジェット方式を用いることにより，ミクロンサイズの 粉体を吐出させることが可能であった。

\section{今後の研究の見通し}

今回ノズルフリーインクジェット用スラリーの基礎 的試験を行い、粘性や表面張力などの影響を調べた。 その結果、現状の方法では通常のインクジェット用ス ラリーと同等の特性が必要であることがわかった。一 方、通常のインクジェットでは使用が困難な粗粒を含 むスラリーの吐出が可能であった。今後、ノズルレス インクジェットを普及されるためには、こうした粗粒 子を含むスラリーや高粘性スラリーの安定した吐出方
法を検討することが必要である。また、超音波発の周 波数や出力の制御による微細液滴の形成方法が望まれ る。

\section{参考文献}

1) 甘利武司監修, “インクジェットプリンター技術と材 料”, シーエムシー出版 pp.1-9, pp.72-110, pp201-213 (1998)

2 ) Yasui, K.: "Pigments Dispersion Technology for Ink Jet Printing Pigments Ink" , J. Imaging Soc. Japan, 38, 195-202 (1999).

3 ) 内藤牧男, 阿部浩也：“ノズルなしのインクジェット 成形システム”超音波テクノ， 16, 46 (2004).

4 ) Elrod, S. A., B. Hadimioglu, B. T. Khuri-Tabub, E. G. Rawson, E. Richley, N. N. Mansour and T. S. Lundgen: "Nozzleless droplet formation with focused acoustic beams" , J. Appl. Phys. 65, 3441 (1989).

5 ) Suzuki, K. and T. Amari: "Dynamics of Jet Printing (1) Ink Droplet Formation and Physical Properties of Jet Ink”, J. Jpn. Soc. Color Mater., 70, 291-299 (1997)

\section{論文発表}

Yokoyama, H., Tsuge, E., Obata, S., Kamai, M., Abe, H. and Naito, M., J. Soc., Powder Tech. Japan, 46, 13-19 (2009). 